\title{
*УДК 658.147
}

Купира M.І., к.е.н., старший викладач

Юхимчук I.M.

Луцький національний технічний університет

\section{ТЕОРЕТИЧНИЙ АСПЕКТ СИСТЕМНОГО ПІДХОДУ ДО ВИЗНАЧЕННЯ ВЛАСНОГО КАПІТАЛУ ПІДПРИЕМСТВА}

У статті систематизовано наукові підходи до визначення сутності власного капіталу. Відповідно до наведених підходів в процесі дослідження узагальнено визначення поняття власного капіталу. Обгрунтовано суть економічної категорії як фінансові відносини 3 приводу формування ефективної структури власних коштів в напрямку забезпечення стабільності підприємства.

Ключові слова: власний капітал, статутний капітал, структура власного капіталу, фінансова стійкість, рентабельність.

Kupyra M., Yukhymchuk I.

\section{THE THEORETICAL ASPECTS SYSTEM APPROACH TO IDENTIFICATION OF THE ENTERPRISE'S OWN CAPITAL}

In the article the scientific going is systematized near determination of essence of property asset. In accordance with the resulted approaches in the process of research generalized of determination of concept of property asset. Grounded essence of economic category as financial relations is concerning forming of effective structure of own money in direction of providing of stability of enterprise.

It is possible to assert on the basis of the conducted research of determination of term «property asset», that he is basis financially economic to activity and characterizes financial independence, independence, effectiveness, in direction of management. As a result of systematization certainly, that authors outline only the personal touches of property asset through the sources of his creation. We prove that it is expedient to examine a property asset in the system of efficiency of capital which straight depends on directions of its optimization structure. Therefore, under a property asset will understand financial relations concerning forming of effective structure of own money in direction of providing of stability of enterprise. The scenario of development and criteria of optimization of capital structure must not independently choose an enterprise in direction of management, in end-point to attain positive a trend on next years. Thus, theoretical researches led to indisputability of influence of property asset on a

* Купира М.I., Юхимчук I.M. 
management and determination of organizational structure of enterprise.

In such direction an enterprise it is necessary expressly to form aims, terms and order of own capital increase, stages of forming and use of operating and additional surpluses, define the system of taxation of operations, related to the increase or diminishing of the chartered capital. Similar steps will give possibility effectively to carry out financially economic activity by the subject of menage in the system maximization it incomes.

Key words: own capital, equity, share capital, equity structure, financial stability, profitability.

Купира М.И., Юхимчук И.Н.

\section{ТЕОРЕТИЧЕСКИЙ АСПЕКТ СИСТЕМНОГО ПОДХОДА К ОПРЕДЕЛЕНИЮ СОБСТВЕННОГО КАПИТАЛА ПРЕДПРИЯТИЯ}

В статье систематизировано научные подходы к определению сущности собственного капитала. Согласно приведенным подходов в процессе исследования обобщено определение понятия собственного капитала. Обоснованно суть экономической категории как финансовые отношения по поводу формирования эффективной структуры собственных средств в направлении обеспечения стабильности предприятия.

Ключевые слова: собственный капитал, уставный капитал, структура собственного капитала, финансовые устойчивость, рентабельность.

Постановка проблеми у загальному вигляді і їі зв'язок 3 важливими науковими та практичними завданнями. В сучасних умовах розвитку ринкової економіки, діяльність підприємств будь-якої форми власності залежить від капіталу та його структури. Тому, досягнення стратегічних цілей можливе лише від побудови ефективної системи формування та управління капіталом. Сьогодні перед власниками та фінансовими менеджерами постають питання результативного управління, системного контролю та своєчасного коригування структури власного капіталу, що системно дозволить максимізувати прибуток, підвищити фінансову стійкість, отримати максимальні показники рентабельності, ліквідності та платоспроможності. Тобто, створити сприятливі умови для безперервності відтворювального процесу в напрямку оптимального формування структури власного капіталу. 
Аналіз останніх досліджень, у яких започатковано вирішення проблеми. Проблеми власного капіталу завжди цікавили науковців. Дослідженням сутності власного капіталу в теоретичному і практичному аспектах, питаннями його формування та використання займалися вітчизняні та зарубіжні вчені, серед яких найбільшою обгрунтованістю вирізняються наукові праці: О.О. Терещенка, А.П. Бобяка, А.П. Семенова, , Я.П. Іщенка, В.П. Мартиненка, К.В. Багацької, І.В. Дем'яненко, Т.Д. Косової, та інших. Однак, дослідження економічної сутності власного капіталу акумулює в собі різні трактування, що не мають єдиного бачення та потребують детального вивчення в напрямку ефективного управління його структурою.

Цілі статті. Основне завдання статті полягає у проведенні дослідження в напрямку побудови системного підходу до визначення власного капіталу підприємства та подання власного бачення ідентифікації даної категорії.

Виклад основного матеріалу дослідження 3 обгрунтуванням отриманих наукових результатів. Фінансовою основою діяльності будь-якого підприємства є власний капітал, головний вимірювач його ринкової вартості, що виступає джерелом погашення збитків, є початковою основою фінансування діяльності підприємства та окреслює його як один 3 найважливіших фінансових показників. Величина, структура та ефективність використання власного капіталу сприяє платоспроможності підприємства, надає можливість оцінити результативність, конкурентні переваги на ринку та сформувати добробут його власників. Динаміка свідчить про якість фінансового менеджменту.

Відтак, наявність оптимальної структури власного капіталу засвідчує надійність та відповідальність підприємства а ефективне управління дозволяє збільшити прибуток, забезпечити інтенсивний розвиток, перевищувати рентабельність інвестованого капіталу над середньозваженою вартістю капіталу. Тобто, ефективна структура власного капіталу дає змогу вплинути на загальний фінансовий стан підприємства, сформувати такий склад активів, що забезпечить власнику самостійність та стабільність підприємства. 
Питання теоретичних аспектів визначення власного капіталу відображені у багатьох наукових працях, що висвітлюють різні погляди на його суть. Так, Я.П. Іщенко [1, с. 146] вважає що власний капітал необхідний фактор виробництва, він включає компоненти боргу, нерозподілений прибуток, привілейовані акції і звичайні акції. О.О. Терещенко [2, с. 13] розглядає як частину майна, яка профінансована власниками корпоративних прав підприємства (завдяки безпосереднім внескам грошових коштів (майнових об'єктів) або внаслідок реінвестування прибутку), і відображається у першому розділі пасиву балансу. У А.П. Бобяка [3, с. 95] власний капітал це загальна вартість засобів, отриманих від засновників у різній формі з повною передачею права власності на ці засоби підприємству, або залишених засновниками на підприємстві, одержаних в процесі діяльності підприємства (як внаслідок власної діяльності, так і безоплатно отриманих).

На основі проведеного дослідження визначення терміну «власний капітал» можна стверджувати, що він $є$ основою фінансово-господарської діяльності та характеризує фінансову незалежність, самостійність, результативність в напрямку управління. В результаті систематизації визначено, що автори окреслюють лише характерні риси власного капіталу через джерела його створення. Ми доводимо, що власний капітал доцільно розглядати в системі ефективності структури капіталу, що напряму залежить від напрямків іiі оптимізації. Тому, під власним капіталом будемо розуміти фінансові відносини з приводу формування ефективної структури власних коштів в напрямку забезпечення стабільності підприємства.

Дослідження сутності та змісту поняття власного капіталу зумовлює потребу у структуруванні елементів власного капіталу підприємства та формуванні класифікації, проведеної за рядом ознак, що є важливим показником у вивченні проблем управління капіталом.

Відповідно до теоретичних засад власного капіталу підприємства можна виділити джерела формування, функції та особливості, що відображають позитивні та негативні сторони використання власного капіталу (рис. 1). 


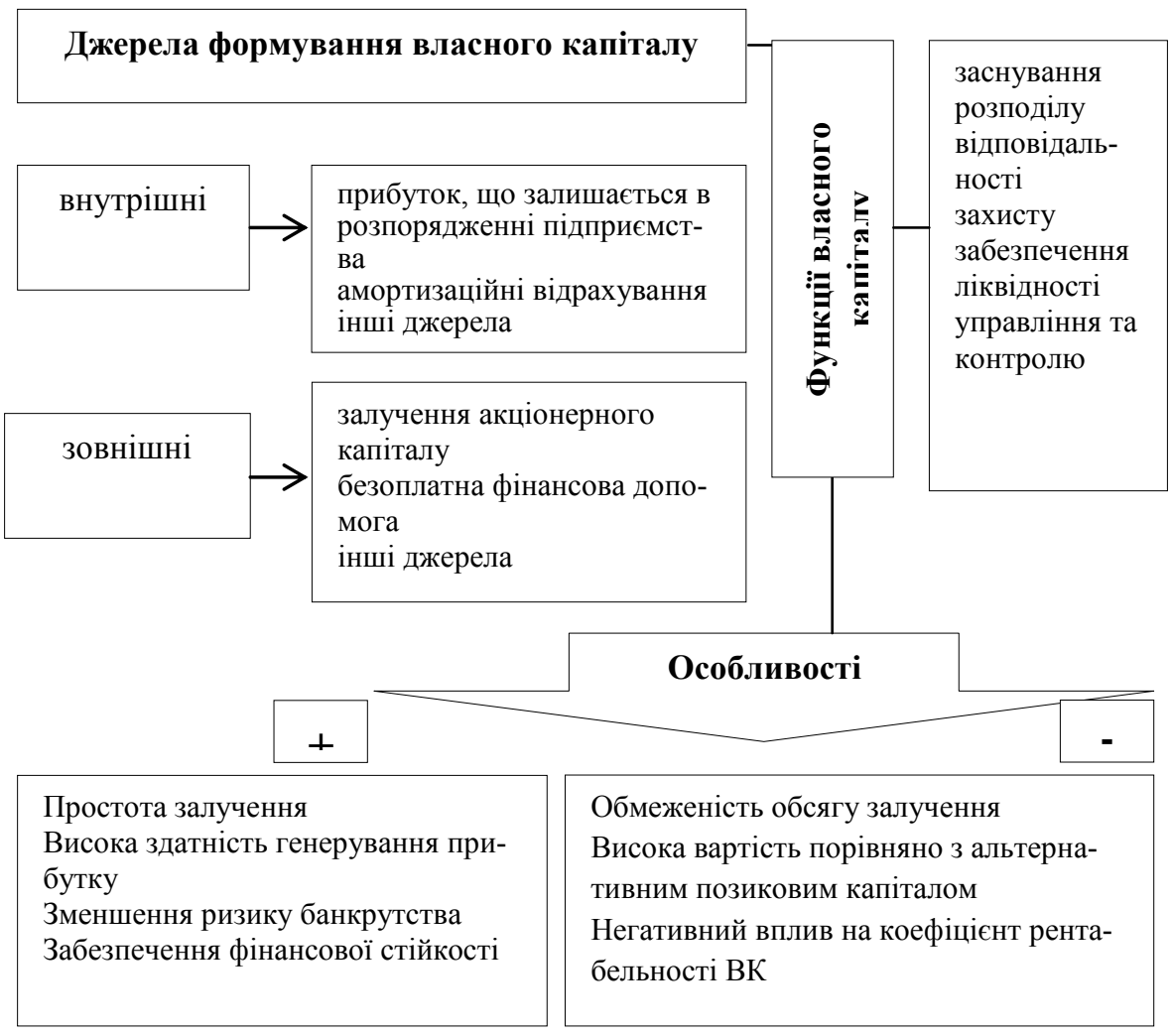

Рис. 1. Схема формування, функціонування та використання власного капіталу

Отже, в процесі формування та використання власного капіталу виконується ряд функцій, серед яких основними є: заснування - фінансова основа для запуску в дію нового суб'єкта господарювання; відповідальності - свого роду кредитне забезпечення для кредиторів підприємства; захисна функція - значення власного капіталу для власників, адже за рахунок власного капіталу покриваються збитки підприємства; забезпечення ліквідності - грошові кошти можуть використовуватися для фінансування операційної, інвестиційної діяльності підприємства та для погашення заборго- 
ваності по позичках, що сприяє підвищенню ліквідності та нарощенню потенціалу довгострокового фінансування.

На сьогодні перед власниками підприємств постають питання складності управління власним капіталом, адже процесі господарської діяльності відбуваються безперервні зміни в напрямку збільшення або зменшення загальної величини, так і окремих його складових.

Тому, раціональне формування та використання власного капіталу вимагає постійного відстеження змін у його розмірах та структурі. Це здійснюється шляхом ретельного ведення бухгалтерського обліку господарських операцій, пов'язаних зі змінами у розмірі та складі власного капіталу. На його зміну, що призводить до збільшення або зменшення власних коштів впливає багато факторів, серед яких основними є: отримання чистого прибутку, розподіл прибутку, переоцінка необоротних активів, внески учасників, вилучення капіталу.

Висновки. Таким чином, теоретичні дослідження довели безперечність впливу власного капіталу на управління та визначення організаційної структури підприємства. В такому напрямку підприємству необхідно чітко формувати цілі, умови та порядок збільшення власного капіталу, етапи формування та використання резервного і додаткового капіталів, визначити систему оподаткування операцій, пов'язаних зі збільшенням або зменшенням статутного капіталу. Подібні кроки нададуть можливість ефективно здійснювати фінансово-господарську діяльність суб'єктом господарювання в системі максимізації свої прибутків.

1. Іщенко Я. П. Теоретичні основи формування власного капіталу підприємства / Я. П. Іщенко, Л. В. Галайда. // Науковий вісник Херсонського державного університету. - 2015. - №15. - С. 146-148.

2. Терещенко О. О. Фінансова діяльність суб'єктів господарювання [Текст] : навч. посіб. / О. О. Терещенко. - К. : КНЕУ, 2013. - 554 с.

3. Бобяк А. П. Організаційно-методичні аспекти обліку власного капіталу / А. П. Бобяк // Экономика и управление. - № 1. - 2011. - С. 91-95.

4. Семенов А. Г. Оптимізація структури капіталу підприємства за критерієм максимізації його рентабельності / А. Г. Семенов, О. В. Ярошевська. // Економіка та підприємництво. - 2014. - №5. - С. 117-128. 